\title{
Penanaman Karakter Kemandirian pada Anak Disabilitas Grahita melalui Pembelajaran Tematik di SDLB Kaliwungu Kudus
}

\author{
Sri Wahyuningsih ${ }^{1]}$, Siti Umaeroh ${ }^{2]}$ \\ ${ }^{1}$ Institut Agama Islam Negeri Kudus \\ ${ }^{2}$ SD Plus Abayasa Islamic School Pati \\ E-mail: ${ }^{1]}$ wahyuningsih@iainkudus.ac.id \\ ${ }^{2]}$ Umaeumaeroh72@gmail.com
}

\begin{abstract}
Abstrak
Karakter kemandirian perlu ditanamkan kepada anak sejak dini terlebih pada anak disabilitas grahita yang memiliki keterbatasan. Hal ini dimaksudkan agar mereka dapat bersikap mandiri dalam melangsungkan kehidupan di masa mendatang. Penelitian ini bertujuan untuk: 1) Mengetahui pelaksanaan pembelajaran tematik kelas IV di SDLB Kaliwungu Kudus.2) Mengetahui pembentukan karakter kemandirian pada anak disabilitas grahita melalui pembelajaran tematik.3) Mengetahui faktor pendukung dan penghambat dalam pembentukan karakter kemandirian anak disabilitas grahita Penelitian ini merupakan jenis penelitian lapangan (field research) dengan menggunakan pendekatan kualitatif. Teknik pengumpulan data dilakukan dengan metode observasi, wawancara, dan dokumentasi. Hasil dari penelitian ini menunjukkan bahwa: 1) Pelaksanaan pembelajaran tematik kelas IV di SDLB Kaliwungu Kudus berjalan dengan baik. 2) Upaya yang dilakukan oleh guru dalam membentuk karakter kemandirian anak disabilitas grahita kelas IV di SDLB Kaliwungu Kudus melalui pembelajaran tematik yaitu dengan menerapkan strategi dan metode yang bervariatif, menggunakan media yang inovatif, bahan ajar yang sesuai tingkat perkembangan anak. Dari upaya tersebut, empat aspek kemandirian yakni aspek intelektual, ekonomi, sosial, dan emosi peserta didik disabilitas grahita telah terbentuk. Pembentukan aspek kemandirian anak disabilitas grahita ini sudah sesuai dengan nilai-nilai keislaman. Hal ini terlihat ketika terjalinnya komunikasi yang baik antara guru dan peserta didik serta penerapan kebiasaan baik dari sekolah dan orangtua 3) Faktor pendukung meliputi semangat dan percaya diri peserta didik yang tinggi, peran guru, lingkungan sekitar. Adapun faktor penghambatnya meliputi IQ peserta didik disabilitas grahita terbatas, kelas dan jumlah guru yang tidak ideal.
\end{abstract}

Kata kunci: Disabilitas Grahita, Karakter, Kemandirian, Pembelajaran Tematik

\section{Promoting Independence Values among Students with Mental Disabilities through Thematic Learning at SDLB Kaliwungu, Kudus}

\begin{abstract}
The character of independence needs to be instilled for children from an early age, especially those with mental disabilities who have limitations. This is conducted in order that they can be independent in carrying out their lives in the future. The present study aims to: 1) Know the implementation of thematic learning for the fourth graders
\end{abstract}


at SDLB Kaliwungu Kudus. 2) Know the character formation of independence among children with mental disabilities through thematic learning. 3) Know the supporting and inhibiting factors in promoting the character of independence of children with mental disabilities. This study used a qualitative approach. The data collection technique was done by using observation, interview, and documentation methods. The results of this study indicate that: 1) the implementation of the fourth-grade thematic learning at SDLB Kaliwungu Kudus is running well. 2) A number of efforts made by the teacher in shaping the independent character of children with mental health disabilities include implementing varied strategies and methods, using innovative media, teaching materials that are appropriate to the students' level of development. From these efforts, four aspects of independence, namely intellectual, economic, social, and emotional aspects of students with mental disabilities have been well formed. The importance of instilling the independence character among children with mental disabilities is in accordance with Islamic values. This can be seen through engaging better communication between teachers and students and the implementation of good habits both from school and parents. 3) Supporting factors include high enthusiasm and selfconfidence of students, the role of the teacher, and the environment. The inhibiting factors include the limited intelligence of students and the limited teachers.

Keywords: Mental Disabilities, Character, Independence, Thematic Learning

\section{PENDAHULUAN}

Pada hakikatnya semua manusia yang ada di dunia ini adalah sama, tidak terkecuali bagi anak yangmemiliki hambatan perkembangan, khususnya bagi penyandang disabilitas. UndangUndang Nomor 8 Tahun 2016 menyebutkan bahwa penyandang disabilitas merupakan setiap orang yang mengalami keterbatasan fisik, intelektual, mental, atau sensorik dalam jangka waktu lama yang dalam berinteraksi dengan lingkungan dapat mengalami hambatan dan kesulitan untuk berpartisipasi secara penuh dan efektif dengan warga Negara lainnya berdasarkan kesamaan hak. Diantara hak penyandang disabilitas salah satunya adalah hak untuk hidup mandiri dan dilibatkan dalam masyarakat terlebih pada anak disabilitas intelektual yakni disabilitas grahita (Permenristek Dikti RI, 2016). Disabilitas grahita adalah anak yang secara nyata mengalami keterbelakangan mental intektual jauh di bawah rata-rata sehingga mengalami kesulitan dalam melakukan tugas-tugas akademik, komunikasi maupun sosial. Hal ini disebabkan karena beberapa faktor seperti halnya kelainan gen, kelainan kromosom, gangguan metabolisme, gizi dan lain sebaginya (Sulthon, 2016).

Dengan demikian dapat disimpulkan bahwa anak tunagrahita merupakan anak yang memiliki kecerdasan di bawah rata-rata serta mengalami hambatan tingkah laku yang terjadi pada masa perkembangannya dan disebabkan karena factor tertentu. American Association on Mental Deficiency (Asosiasi Amerika Mengenai Disabilitas Grahita) mendefinisikan bahwa anak disabilitas grahita memiliki kelainan intelektual di bawah rata-rata yaitu IQ 84 kebawah berdasarkan tes sebelum usia 16 tahun. Sedangkan menurut Japan League for Mentally Retarded, anak dengan fungsi intelektual lamban yaitu memiliki IQ 70 ke bawah. Angka-angka tersebut menunjukkan adanya hambatan dalam 
perilaku adaptif (Putranto, 2015). Artinya, anak yang menderita disabilitas grahita tergolong luar biasa karena mereka mempunyai kekurangan atau keterbatasan dibanding anak normal lainnya.

Sebagaimana diketahui dalam lingkungan masyarakat, tingkah laku anak disabilitas grahita akan berbeda dengan anak normal pada umumnya. Perbedaan yang dimaksud adalah anak disabilitas grahita mengalami kondisi yang kurang beruntung, karena dalam diri mereka memiliki kekurangankekurangan yang dapat menghambat dalam melakukan aktifitas sehari-hari. Hambatan yang dialami anak disabilitas grahita diantaranya dari segi akademik, kapasitas belajar anak disabilitas grahita terbatas lebih-lebih kapasitasnya mengenai hal-hal yang abstrak. Mereka cenderung menghindar dari perbuatan berpikir, sulit memusatkan perhatian, cenderung cepat lupa, sukar membuat kreasi baru serta rentang perhatiannya pendek (Rochyadi, 2012).

Dari segi sosialnya, anak disabilitas grahita sulit menyesuaikan diri terhadap perubahan, sulit dalam menggeneralisasikan sesuatu, sulit dalam keterampilan menolong diri sendiri dan mereka juga tidak dapat bergaul dengan teman sebayanya melainkan mereka hanya dapat bergaul dengan teman-teman yang lebih muda dari usianya. Karakteristik anak disabilitas grahita dilihat dari aspek fisik, secara keseluruhan anak tidak memiliki perbedaan dengan anak umumnya kecuali untuk anak down syndrome yang memiliki wajah khas. Perbedaan menonjol dapat dilihat dari aspek psikis yaitu dalam kaitannya dengan karakteristik psikologis dan perilaku anak disabilitas grahita. Beberapa anak disabilitas grahita cenderung mengalami defisit dalam hal perhatian, ingatan, bahasa, mengatur diri, motivasi, dan perkembangan sosial (Wulandari, 2017).

Berdasarkan beberapa hambatan yang dialaminya, masalah yang dihadapi anak disabilitas grahita diantaranya meliputi konteks kehidupan dan pendidikan. Pertama, mereka kesulitan dalam melakukan aktifitas sehari-hari seperti makan, mandi, menggosok gigi, memakai baju dan lain sebagainya. Kedua, kesulitan dalam belajar. Tidak dapat dipungkiri lagi bahwa mereka tentu mengalami kesulitan belajar, terutama dalam bidang akademik (misalnya matematika, IPA, bahasa). Ketiga, kesulitan dalam hal penyesuaian diri. Disadari bahwa kemampuan penyesuaian diri dengan lingkungan sangat dipengaruhi oleh tingkat kecerdasan. Anak disabilitas grahita cenderung tidak mampu untuk mengarahkan diri sendiri sehingga segala sesuatu yang terjadi pada dirinya bergantung pengarahan dari luar, seperti orangtua ataupun pengasuh. Sejalan dengan permasalahan yang dialaminya tersebut, anak disabilitas grahita perlu diberikan pengajaran terkait pendidikan karakter agar mereka tidak terus menerus bergantung kepada orang lain dalam melakukan segala aktifitas. Pendidikan karakter dikembangkan untuk meningkatkan perilaku positif peserta didik dan mengatasi permasalahan perilaku peserta didik, termasuk mengatasi berbagai hambatan yang dialami anak disabilitas grahita yakni retardasi mental (Listiady, 2017).

Pendidikan karakter merupakan pembentukan peserta didik agar mempunyai karakter yang baik dan diwujudkan dalam perilaku keseharian, salah satunya adalah nilai karakter kemandirian. Kemandirian juga dapat dibentuk melalui berbagai stimulasi yang datang dari lingkungan, seperti pola asuh orangtua, sistem pendidikan 
di sekolah, dan sistem kehidupan di masyarakat. (Wahyuningsih, 2017b).

\section{Mengingat} pentingnya menanamkan karakter kemandirian pada anak sejak dini, maka dalam hal ini lembaga pendidikan khususnya sekolah dipandang sebagai tempat yang strategis untuk membentuk kemandirian mereka. Selain itu, guru atau pendidik terutama di sekolah dasar memiliki peran utama dalam mendidik karakter siswa di sekolah (Afandi et al., 2021).

Pengembangan sikap dan karakter dalam suatu lembaga pendidikan, ditempatkan sejajar dan sama pentingnya dengan pengembangan kemampuan kognitif dan psikomotorik peserta didik (Sultan, 2015; Wahyuningsih, 2017a, 2017b). Hal ini merupakan suatu kebijakan pemerintah yang telah dikemas dalam kurikulum terbaru yaitu kurikulum 2013 dan menjadikan pembelajaran tematik sebagai pendekatan pembelajaran yang dipilih. Melalui pendekatan pembelajaran tematik, peserta didik akan merasakan secara langsung materi pelajaran yang dipelajari dengan pengalaman nyata yang diperoleh di lapangan termasuk kaitannya dalam hal kemandirian.

Secara sederhana, pembelajaran tematik dapat diartikan sebagai pembelajaran yang memuat konsep pembelajaran terpadu yang menggunakan tema untuk mengaitkan beberapa mata pelajaran sehingga dapat memberikan pengalaman bermaka kepada peserta didik (Malawati \& Kadarwati, 2017). Tema pembelajaran diambil dari hal-hal konkret yang berkaitan dengan alam dan kehidupan manusia seperti keluarga, kegemaran, binatang, tumbuhan dan lain sebagainya (Ahmadi \& Amri, 2014).

Dari tema inilah seorang pendidik kemudian menghubungkan dengan materi pelajaran yang relevan guna mencapai kompetensi yang ditargetkan. Pembelajaran tematik di sekolah dasar akan sangat membantu peserta didik dalam membentuk pengetahuannya karena pembelajaran tematik berfungsi untuk memberikan kemudahan bagi peserta didik dalam memahami dan mendalami konsep materi yang tergabung dalam tema. Sama seperti pada sekolah umumnya layanan pendidikan bagi penyandang disabilitas juga menerapkan model pembelajaran tematik yang termuat dalam kurikulum 2013 penyandang disabilitas. Dalam hal ini, pembelajaran tematik dapat berpotensi untuk mengembangkan kepercayaan diri serta kemandirian peserta didik, karena seorang guru dituntut untuk membuat perencanaan yang sangat cermat akan menyediakan lingkungan yang merangkul kepribadian setiap peserta didik termasuk peserta didik disabilitas grahita (Hajar, 2013).

Meskipun dari berbagai karakteristik anak disabilitas grahita tidak bisa mengikuti pembelajaran seperti anak normal seusianya, mereka juga memerlukan bekal pendidikan terkait pembelajaran tematik. Melalui bahan ajar yang meliputi tema-tema yang relevan dengan tingkat perkembangan mereka serta didukung strategi, metode dan media yang bervariasi maka nilai karakter kemandirian akan tercapai dengan baik. Bahan ajar merupakan media yang tepat untuk mengintegrasikan pendidikan karakter. Sesuai dengan tuntutan kurikulum 2013, nilai-nilai dan karakter bangsa merupakan bagian yang integral dalam setiap kegiatan belajar. Nilfai karakter bukan merupakan pelajaran sendiri tetapi menyatu dalam proses pembelajaran. Dalam hal pemanfaatan bahan ajar, pembelajaran tematik tema 3 "tugasku sehari-hari” dapat membantu meningkatkan kemandirian anak 
disabilitas grahita. Mereka sangat membutuhkan kemandirian baik dalam hal kegiatan belajar, mengurus diri sendiri, berinteraksi dengan orang lain sesuai dengan kemampuan mereka masing-masing lewat sebuah layanan pendidikan.

Berdasarkan data yang peneliti peroleh dari lapangan menyatakan bahwa pembelajaran tematik pada lembaga disabilitas tidak sama dengan lembaga sekolah normal pada umumya, akan tetapi terjadi keterlambatan dan lebih disederhanakan terkait materi ajar yang disampaikan. Seperti halnya materi ajar yang digunakan pada kelas III adalah buku ajar kelas I, untuk kelas IV adalah buku ajar kelas II begitupun berikutnya. Hal ini terjadi karena anak pada usia kelas rendah belum bias beradaptasi dengan orang lain apalagi dalam hal menerima materi pembelajaran. Oleh sebab itu, dalam hal ini peneliti melakukan penelitian pada peserta didik disabilitas grahita kelas IV karena anak disabilitas grahita kelas IV sudah mampu beradaptasi dengan lingkungan sekitar dan mulai mampu memahami bahasa lawan bicaranya sehingga dengan begitu mereka akan mudah menerima materi pembelajaran dengan baik. Sekolah Luar Biasa (SLB) merupakan salah satu lembaga pendidikan bagi penyandang disabilitas yang sangat penting demi membentuk jiwa kemandirian mereka semua. Sekolah Dasar Luar Biasa Kaliwungu Kudus (SDLB Kaliwungu Kudus) merupakan salah satu lembaga pendidikan yang diperuntukkan bagi penyandang disabilitas, salah satunya yaitu disabilitas grahita. Anak disabilitas grahita pada umumnya mereka hidup bergantung dengan orang lain karena ketidakmampuannya dalam mengurus diri sendiri. Oleh sebab itu salah satu tujuan pokok SDLB Kaliwungu Kudus dalam mendidik anak disabilitas tersebut, agar mereka bisa mandiri. Untuk membentuk kemandirian penyandang disabilitas khususnya disabilitas grahita, di SDLB Kaliwungu Kudus juga menjadikan pembelajaran tematik sebagai salah satu pelajaran guna mencapai sebuah karakter. Dengan melalui pembelajaran tematik peserta didik akan diberikan pengalaman secara langsung terkait materi pelajaran dengan apa yang dialami peserta didik secara nyata.

Artikel ini membahas tentang proses pelaksanaan pembelajaran tematik kelas IV di SDLB Kaliwungu Kudus, proses pembentukan karakter kemandirian pada anak disabilitas grahita melalui pembelajaran tematik kelas IV di SDLB Kaliwungu Kudus dan faktor pendukung dan penghambat yang dialami oleh guru dalam pembentukan karakter kemandirian pada anak disabilitas grahita melalui pembelajaran tematik kelas IV di SDLB Kaliwungu Kudus.

\section{METODE}

Jenis penelitian yang digunakan peneliti adalah penelitian kualitatif yang dimaksudkan sebagai jenis penelitian yang temuan-temuannya tidak diperoleh melalui prosedur statistik atau bentuk hitungan lainnya. Jadi pada dasarnya, penelitian ini dilakukan untuk memperoleh data atau informasi sesuai dengan fakta di lapangan yaitu tentang pembentukan karakter kemandirian pada anak disabilitas grahita melalui sebuah pembelajaran tematik di SDLB Kaliwungu Kudus. Pendekatan dalam penelitian ini menggunakan penelitian lapangan (field research), yang mengharuskan seorang peneliti terjun langsung dalam suatu penelitian dengan tujuan untuk dapat mengamati secara alamiah dari objek yang sedang diteliti tersebut. Guna memperoleh data yang akurat dan jelas dalam lapangan, maka 
peneliti terjun langsung di kelas IV SDLB Kaliwungu Kudus. Data dikumpulkan melalui observasi, wawancara, dan dokumentasi. Adapun pihak yang peneliti wawancarai dalam penelitian ini adalah kepala sekolah, waka kurikulum, guru kelas, dan peserta didik disabilitas grahita sedang dan ringan kelas IV. Di sini data yang diperoleh berupa data tentang stuktur organisasi, data keadaan pendidik dan peserta didik, RPP (Rencana Pelaksanaan pembelajaran) kelas IV SDLB Kaliwungu Kudus. Adapun langkah-langkah dalam analisis data meliputi Pengumpulan Data (Data Collection), Reduksi Data (Data Reduction). Selanjutnya, penyajian Data (Data Display) yakni data yang selesai direduksi, maka langkah selanjutnya adalah mendisplay data. Dalam penelitian kualitatif penyajian data biasa dilakukan dengan bentuk uraian singkat, bagan, atau hubungan antar kategori. Langkah selanjutnya adalah verifikasi (data verification) yakni verifikasi atau penarikan kesimpulan.

\section{HASIL DAN PEMBAHASAN Pelaksanaan Pembelajaran Tematik Kelas IV di SDLB Kaliwungu Kudus}

Pelaksanaan pembelajaran sebelumnya diawali dengan persiapan. Setelah guru melakukan persiapan, langkah selanjutnya yaitu memasuki proses pelaksanaan pembelajaran yang terdiri dari tiga kegiatan, yaitu kegiatan awal, kegiatan inti dan kegiatan akhir. Pelaksanaan pembelajaran tema 3 sub tema "tugasku sehari-hari di sekolah" terdiri dari pelajaran Bahasa Indonesia, Matematika, Seni Budaya dan Prakarya (SBDP). Pada kegiatan awal, guru terlebih dahulu mengkondisikan kelas serta menggali pengalaman peserta didik. Kegiatan inti, yaitu kegiatan memasuki materi. Guru menyampaikan materi pembelajaran dengan menggunakan strategi dan metode yang bervariatif meliputi metode ceramah, metode tanya jawab, metode penugasan, dan metode bermain simulasi. Selain metode, guru juga menggunakan media pembelajaran berupa arah mata angin, gambar sekolah, gambar uang mainan, uang logam dan uang kertas asli, kelereng, spidol, dan papan tulis.

Media arah mata angin dan gambar sekolah digunakan untuk menjelaskan materi dan bermain simulasi terkait "lingkungan geografis sekolah". Kemudian media gambar uang mainan untuk menjelaskan materi "Nilai pecahan mata uang", lalu menggunakan uang asli logam dan kertas untuk penugasan dan bermain simulasi. Terakhir, menggunakan media spidol dan papan tulis untuk menulis lirik lagu "abang tukang bakso" pada materi "menyanyi dan menari berdasarkan isi lagu. Setelah melalui tahap perencanaan dan pelaksanaan pembelajaran, guru melakukan evaluasi. Untuk mengetahui tingkat kemampuan anak disabilitas grahita, guru menggunakan evaluasi melalui pengamatan. Sesuai hasil wawancara dengan Khusfiana selaku guru kelas IV menyatakan bahwa untuk anak disabilitas grahita penilaian memang penilaian proses karena dalam satu kelas untuk akademik membaca dan menulis belum semuanya bisa hanya beberapa saja yang bisa itupun juga perlu pendampingan. Pada tahap evaluasi pada tema 3 sub tema "tugasku sehari-hari di sekolah", guru melakukan penilaian melalui pengamatan dengan menggunakan lembar observasi. Adapun penilaian yang dilakukan meliputi tiga ranah, yaitu ranah kognitif, ranah afektif, dan ranah psikomotorik. Dari aspek pengetahuan, guru mengamati ketika proses tanya jawab peserta didik bias atau tidak 
menjawabnya. Kemudian, dari aspek keterampilan dilihat ketika mereka maju di depan kelas untuk menunjukkan denah sekolah, maju simulasi menyetarakan uang, maju menyanyi dan memeragakan sesuai isi lagu sudah tepat apa belum.

Dari aspek sikap dapat dilihat berdasarkan perilaku sesuai ajaran agamanya serta interaksi peserta didik dengan guru ataupun sesama teman. Adapun ketuntasan belajar minimal (KBM) untuk pembelajaran tematik pada pelajaran Bahasa Indonesia, Matematika, dan Seni Budaya dan Prakarya di SDLB Kaliwungu Kudus yaitu 67. Namun di SDLB, nilai KBM tidak menjadi nilai acuan yang sebenarnya untuk mengatakan peserta didik sudah berhasil atau tidak, akan tetapi pencapaian keberhasilan peserta didik pada penyandang disabilitas dilihatberdasarkan perkembangan pada kondisi serta kemampuan masingmasing peserta didik sesuai jenis hambatannya. Jadi, di SDLB sendiri tidak ada istilah anak tidak naik kelas, karena penilaiannya didasarkan pada perbandingan atas dirinya sendiri yaitu yang sebelumnya mereka tidak bisa kemudian setelah dibimbing dan dipelajari perlahan-lahan menjadi bisa. Berdasarkan tahapan evaluasi tersebut dapat diketahui bahwa, pada materi tema 3 sub tema "tugasku sehari-hari di sekolah" materi"lingkungan geografis sekolah", peserta didik disabilitas grahita hanya mampu mencapai Kompetensi dasar (KD 1.1), yakni mengemukakan kosa kata tentang lingkungan geografis, kehidupan ekonomi, sosial, dan budaya lingkungan sekitar dalam bahasa Indonesia atau bahasa daerah melalui lisan atau eksplorasi lingkungan dengan catatan masih memerlukan bimbingan. Pada materi ini, hanya satu atau dua anak yang bisa karena keterbatasan intelektual setiap anak berbeda.Untuk (KD 1.2) ratarata anak belum bias Padamateri"nilai pecahan mata uang",anak disabilitas grahita sudah mampu mencapai semua KD (2.1) (2.2), yakni mengidentifikasi nilai dan kesetaraan pecahan mata uang, kemudian mengurutkan nilai mata uang serta berbagi kesetaraan pecahan mata uang dengan catatan tidak diartikan mampu seperti anak normal umumnya, akan tetapi anak disabilitas grahita sedang dan ringan mampu dengan kondisi dan keterbatasan mereka masing-masing. Mereka ada yang sudah mampu mengidentifikasi nilai uang dalam jumlah besar misal sampai 10.000 rupiah, ada yang hanya sampai jumlah kecil seperti 2.000 rupiah. Ada yang sudah mampu menyetarakan dan mengurutkan nilai Terakhir materi "menyanyi dan menari berdasarkan isi lagu", anak hanya mampu mencapai KD (3.2) yakni memeragakan gerak keseharian dan alam tari. Untuk KD (3.1) menyanyikan lagu dengan gerak keseharian dan alam, hanya satu atau dua anak saja yang bisa meskipun pengucapannya tidak terlalu jelas dan itupun perlu bimbingan. Mereka memiliki hambatan dalam berkomunikasi, namun mereka paham dalam memeragakan gerak isi lagu dengan dipandu oleh guru (Observasi Di SDLB Kaliwungu Kudus, 2019).

Pengembangan sikap dan karakter dalam suatu lembaga pendidikan, ditempatkan sejajar dan sama pentingnya dengan pengembangan kemampuan kognitif dan psikomotorik peserta didik (Sultan, 2015). Hal ini pula yang telah diterapkan di SDLB Kaliwungu Kudus dalam mengembangkan karakter kemandirian anak disabilitas grahita. Karakter kemandirian merupakan suatu hal yang penting untuk ditanamkan pada peserta didik salah satunya dengan 
mengintegrasikan melalui kegiatan pembelajaran. Kegiatan pembelajaran di SDLB Kaliwungu kudus dapat tercapai secara maksimal, karena sebelum pelaksanaannya guru terlebih dahulu melakukan perencanaan yang cermat agar tidak terjadi kesalahan dari awal proses pelaksanaan hingga tahap akhir pembelajaran. Sesuai yang termuat dalam Permendikbud RI No. 65 Tahun 2013 tentang Standar Proses pada lampirannya Bab III yaitu perencanaan pembelajaran dirancang dalam bentuk silabus dan rencana pelaksanaan pembelajaran (RPP) yang mengacu pada standar isi. Perencanaan pembelajaran meliputi penyusunan rencana pelaksanaan pembelajaran dan penyiapan media dan sumber belajar, perangkat penilaian pembelajaran, dan skenario pembelajaran (Evitasari dkk, 2021; Prastowo, 2015). Demikian yang dilakukan oleh ibu Khusfiana guru kelas IV, sebelum dilaksanakan kegiatan pembelajaran beliau terlebih dahulu membuat RPP kemudian menyiapkan materi, media dan bahan ajar yang mendukung pemahaman anak (Khusfiana, 2019). Kemudian setelah menyusun sebuah perencanaan, guru masuk pada tahap proses pelaksanaan pembelajaran. Ibnu Hajar mengatakan bahwa, pada tahap pelaksanaan pembelajaran tematik terbagi menjadi tiga tahapan yaitu tahapan pendahuluan, tahapan inti, dan tahapan penutup (Hajar, 2013). Seperti yang dilakukan oleh ibu Khusfiana S.Pd, pada proses pelaksanaan pembelajaran tematik beliau membagi menjadi tiga kegiatan, yaitu kegiatan awal kegiatan inti dan kegiatan akhir (Observasi Di SDLB Kaliwungu Kudus, 2019). .

Hal tersebut sesuai dengan pernyataan Ibnu Hajar yang mengatakan bahwa, pada kegiatan awal guru harus berupaya menciptakan suasana belajar yang kondusif agar para peserta didik bisa memusatkan konsentrasi mereka terhadap kegiatan pembelajaran dan menggali pengalaman peserta didik mengenai tema yang akan dipelajari (Hajar, 2013). Hal ini terlihat ketika guru masuk ke dalam kelas lalu mengkondisikan peserta didik untuk duduk ditempat masing-masing kemudian baru membuka dengan mengucapkan salam. Setelah selesai guru melakukan apersepsi dengan mengaitkan materi dengan pengalaman sehari-hari peserta didik. Setelah kegiatan awal, kemudian masuk pada kegiatan inti yaitu proses penyampaian materi ajar.Guru menggunakan berbagai strategi atau metode yang bervariasi, bahkan dalam penyajian tema pembelajaran, ia juga bisa melakukannya secara kelompok kecil, individual (perorangan) atau klasikal (Hajar, 2013).

Dalam hal ini, Khusfiana selaku guru menyampaikan materi bukan sekedar ceramah kepada peserta didik. Namun, beliau juga menggunakan strategi dan metode yang bervariatif, diantaranya metode tanya jawab, metode penugasan, dan metode bermain simulasi (Khusfiana, 2019). Tugas seorang guru dalam meciptakan kegiatan pembelajaran yang menyenangkan, supaya peserta didik mudah menerima materi pelajaran dengan maksimal. Pada kegiatan akhir, tugas guru adalah menenangkan peserta didiknya yang telah mengikuti semua proses pembelajaran dari awal hingga akhir, laluguru harus melakukan beberapa hal pokok seperti menyimpulkan pembelajaran yang telah dilakukan, mengungkapkan hasil pembelajaran tematik apa adanya baik dalam bentuk angka-angka, nilai maupun pandangan guru secara lisan, memberi kesempatan kepada peserta didik untuk mengomentari seputar pembelajaran dan memberi nasihat dan 
pesan-pesan moral kepada peserta didik (Hajar, 2013)

Sesuai yang dilakukan oleh Khusfiana, sebelum mengakhiri kegiatan pembelajaran, guru terlebih dahulu membimbing untuk diam dibangkunya masing-masing lalu menyimpulkan materi secara berulangulang. Kemudian, mengungkapkan hasil pembelajaran dengan memberikan tepuk tangan kepada peserta didik. Pada kegiatan akhir ini, guru tidak melakukan kegiatan untuk memberikan kesempatan kepada peserta didik untuk mengomentari seputar pembelajaran. Hal ini dikarenakan kemampuan komunikasi anak disabilitas grahita tidak begitu jelas, mereka hanya bias menangkap namun untuk mengutarakan secara jelas masih sulit. Terakhir, guru mengingatkan untuk belajar di rumah. Setelah guru melakukan perencanaan, pelaksanaan, kemudian masuk pada tahap evaluasi. Penggunaan jenis evaluasi harus disesuaikan dengan pencapaian hasil belajar yang ditargetkan oleh guru. Target belajar atau sasaran belajar menurut Bloom yang dikutip oleh Ida Farida mencakup tiga domain (ranah), yaitu kognitif (pengetahuan), psikomotor (keterampilan), dan afektif (sikap) (Farida, 2017).

Sama halnya yang dilakukan oleh Khusfiana selaku guru kelas IV, beliau melakukan penilaian meliputi tiga ranah yaitu pengetahuan melalui tanya jawab, keterampilan dilihat dari ketepatan, kecepatan atau keterlambatan serta sikap peserta didik berdasarkan ajaran agamanya, serta rasa percaya diri peserta didik ketika berinteraksi dengan orang lain. Alat evaluasi yang digunakan pada anak disabilitas grahita sama halnya seperti yang digunakan anak normal. Penggunaan alat evaluasi seperti tulisan, lisan dan perbuatan bagi anak disabilitas grahita harus ditinjau lebih dahulu bagaimana keadaan anak disabilitas grahita yang akan dievaluasi (Rochyadi, 2012).

\section{Pembentukan Karakter Kemandirian pada Anak Disabilitas Grahita melalui Pembelajaran Tematik kelas IV di SDLB Kaliwungu Kudus}

Upaya yang dilakukan oleh para guru di SDLB Kaliwungu Kudus untuk membentuk karakter kemadirian peserta didik disabilitas antara lain:

\section{Menggunakan strategi dan metode bervariatif}

Kegiatan pembelajaran tentu tidak lepas dari adanya stategi dan metode yang pendidik lakukan agar pembelajaran dapat berhasil. Begitupun yang dikatakan oleh Khusfiana selaku guru kelas IV bahwa pelaksanaan pembelajaran tematik untuk membentuk karakter kemandirian anak disabilitas grahita dapat dikatakan berhasil jika diterapkannya strategi dan metode yang disukai anak.Emosi anak lebih kena jika anak diajak belajar dengan hal-hal yang bervariatif dan tidak monoton (Khusfiana, 2019). Berdasarkan hasil pengamatan pada pelaksanaan pembelajaran tematik tema 3 sub tema "tugasku sehari-hari di sekolah" strategi yang digunakan guru yaitu pertama pendidik menjelaskan materi terlebih dahulu kemudian peserta didik maju satu persatu, setelah itu peserta didik maju dengan kelompok. Selaras dengan apa yang dikatakan bapak Sutarno selaku waka kurikulum bahwa: "Disabilitas grahita sebelum K13 penekanannya sudah begitu pembelajaran disamping klasikal ya individual hal tersebut diupayakan agar anak bisa memiliki karakter berani, percaya diri dan lain sebaginya. Untuk model pembelajaran ya guru mengusahakan secara kontekstual, kalau sekedar berbicara anak disabilitas 
grahita tidak bisa memahami” (Sutarno, 2019).

Kemandirian anak disabilitas grahita dapat terbentuk dengan beberapa metode, diantaranya metode ceramah, metode tanya jawab, metode penugasan, dan metode bermain simulasi. Pertama, metode ceramah. Guru terlebih dahulu menjelaskan materi secara perlahan dan berulang-ulang kepada peserta didik, hal ini dapat membentuk kemandirian intelektual peserta didik. Kedua, metode tanya jawab. Untuk mengetahui seberapa kemampuan peserta didik, guru memberikan pertanyaan terkait materi "tugasku sehari-hari di sekolah", peserta didik menjawab meskipun masih memerlukan bimbingan. Selain membentuk kemandirian intelektual, metode tanya jawab ini dapat membentuk kemandirian sosial peserta didik melalui interaksi peserta didik secara langsung dengan guru. Ketiga, metode penugasan. Guru memberikan tugas membaca, mengerjakan soal, dan maju memperagakan isi lagu di depan kelas. Jika mereka bisa, guru bersama peserta didik bersama-sama memberikan tepuk tangan. Jika belum bisa, guru perlahan mengarahkan. Hal ini dapat membentuk kemandirian intelektual dan kemandirian sosial peserta didik ketika berinteraksi di depan kelas. Terakhir, metode bermain simulasi. Pada metode ini peserta didik praktik secara langsung ada keterkaitan antara materi dengan kehidupan seharihari peserta didik. Penerapan metode bermain simulasi pada materi "letak geografis sekolah" dapat membentuk kemandirian intelektual, kemandirian sosial dan kemandirian emosi peserta didik. Sedangkan, penerapan metode bermain simulasi jual beli pada materi "nilai pecahan mata uang" dapat membentuk semua aspek kemandirian, baik dari kemandirian intelektual, kemandirian ekonomi, kemandirian sosial, maupun kemandirian emosi peserta didik.

\section{Menggunakan media yang inovatif}

Upaya guru SDLB Kaliwungu

Kudus dalam membentuk karakter kemandirian anak disabilitas grahita melalui pembelajaran tematik adalah menggunakan media yang inovatif. Dengan didukung beberapa media yang menarik dan sesuai dengan isi materi pembelajaran, maka peserta didik akan lebih memahami isi materi dan tidak hanya mengetahui secara abstrak saja. Dalam hal ini para guru menyiapkan alat dan bahan pembelajaran sesuai materi yang akan diajarkan. Sebagai contoh pada materi "lingkungan geografis sekolah", guru menggunakan media arah mata angin dan gambar sekolah untuk mendukung pemahaman peserta didik ketika guru menyampaikan materi pelajaran, hal ini dapat membentuk kemandirian intelektual peserta didik. Kemudian, media ini juga digunakan saat bermain simulasi dengan teman sebangku, hal ini dapat membentuk kemandirian sosial peserta didik ketika mereka berinteraksi dengan guru dan sesame teman. Selain kemandirian intelektual dan sosial, media ini juga dapat membentuk kemandirian emosi peserta didik. Peserta didik emosinya lebih senang ketika mereka diajak bermain dengan menggunakan media yang menarik, lalu mereka juga belajar bagaimana cara menghargai teman.

Pada pelajaran matematika materi "nilai pecahan mata uang", guru menggunakan media gambar uang, uang logam dan uang kertas asli serta kereleng. Guru menjelaskan materi menggunakan media gambar uang yang telah dicetak oleh guru, hal tersebut dapat membentuk kemandirian intelektual peserta didik. Kemudian, guru menggunakan uang logam dan 
uang asli saat peserta didik diberi tugas untuk menyetarakan uang di depan kelas, hal ini dapat membentuk kemandirian intelektual dan kemandirian sosial peserta didik. Selanjutnya, guru menggunakan media uang logam dan kertas asli untuk bermain simulasi jual beli kelereng dengan teman sebangku, hal ini dilakukan supaya peserta didik dapat merasakan secara langsung keterkaitan isi materi dengan kehidupan sehari-hari dalam mengelola uang. Dari penggunaan media tersebut kemandirian intelektual, kemandirian ekonomi, kemandirian sosial dan kemandirian emosi peserta didik dapat terbentuk.

\section{Bahan ajar sesuai tingkat Perkembangan Anak}

Upaya terakhir yang digunakan oleh guru kelas IV SDLB Kaliwungu Kudus yaitu menggunakan bahan ajar yang sesuai dengan tingkat perkembangan anak. Anak disabilitas grahita adalah anak yang memiliki hambatan IQ dan tingkah laku yang tidak sesuai dengan usianya. Pentingnya bahan ajar yang tepat dalam pembelajaran juga dengan pernyataan Primasari, Ulia, \& Yustiana ( 2021) yang menekankan pemilihan bahan ajar. Oleh sebab itulah bahan ajar yang digunakan di SDLB Kaliwungu Kudus lebih disederhanakan dan disesuaikan tingkat perkembangan peserta didik. Adapun bahan ajar yang digunakan untuk kelas IV, guru menggunakan buku tematik kelas II, sedemikian pula untuk kelaskelas yang lain juga lebih disederhanakan. Kemudian guru juga mencari beberapa referensi di internet sesuai isi materi yang nantinya akan yang digunakan guru, karakter kemandirian peserta didik dapat terbentuk dari semua aspek dengan hambatan dan kondisi masing-masing. Kemandirian anak disabilias grahita kelas IV SDLB Kaliwungu Kudus dapat terbentuk melalui upaya-upaya guru yang dilakukan melalui pembelajaran tematik buku kelas II tema 3 sub tema "kegiatanku sehari-hari disekolah". Hal ini dapat peneliti uraikan sebagai berikut: Kemandirian dari aspek intelektual, peserta didik mampu menjawab dan mengerjakan tugas dari guru meskipun memerlukan bimbingan. Hal ini dibuktikan bahwa secara intelektual anak bisa menjawab pertanyaan dari guru meskipun ada beberapa yang masih memerlukan bimbingan. Kemudian, peserta didik diberi tugas untuk maju di depan kelas. Sama dengan penelitian yang dilakukan oleh Wuri Wuryandani, dkk.dalam jurnal penelitiannya bahwa upaya pengembangan kemandirian peserta didik melalui proses pembelajaran yaitu dengan melakukan aktivitas penugasan (Wuryandani et al., 2016).

Kemandirian dari sisi ekonomi, anak sudah mampu mengelola uang sakunya sendiri. Hal ini berkaitan dengan pemahaman peserta didik terhadap materi yang telah diajarkan yaitu "nilai pecahan mata uang". Pada pelaksanaan pembelajaran pendidik menggunakan media dan metode yang disukai peserta didik sehingga materi pembelajaran dapat terintegrasi dengan baik.

Hal itu pula yang dilakukan oleh guru kelas IV SDLB Kaliwungu Kudus, guru menggunakan uang logam dan uang kertas sebagai metode dan media untuk mendukung penyampaian materi ajar. Jika guru hanya menjelaskan materi saja tanpa didukung oleh media, maka peserta didik disabilitas grahita tidak dapat memahami materi dengan baik. Secara sosial, peserta didik sudah memiliki keberanian dan percaya diri ketika berinteraksi dengan guru dan sesama teman. Hal itu terlihat dari awal proses pelaksanaan pembelajaran 
hingga akhir pelaksanaan pembelajaran. Peserta didik berani menjawab pertanyaan, berani maju mengerjakan di depan kelas, dan percaya diri ketika bermain simulasi di depan kelas dengan teman sebangku.

Kemandirian dari aspek sosial dapat dilihat ketika berlangsungnya pelaksanaan pembelajaran, yakni peserta didik diberi tugas untuk maju satu persatu, kemudian peserta didik juga diberi tugas untuk maju di depan kelas dengan teman sebangku (bermain simulasi) menggunakan media arah mata angin, gambar sekolah, uang logam dan uang kertas, dan kelereng. Berkaitan dengan kegiatan tersebut, guru dapat membentuk keberanian serta percaya diri peserta didik ketika berinteraksi dengan pendidik ataupun dengan teman-teman. Hal ini diperkuat oleh Sutarno selaku waka kurikulum bahwa, untuk mengetahui kemandirian sosial anak disabilitas grahita dalam proses pembelajaran, salah satunya dilihat dari kerjasama peserta didik dengan temannya ketika mengerjakan tugas. Dalam hal ini kerjasama yang dimaksud yaitu saling berbagi, ketika anak melihat ada temannya yang kesulitan, mereka cepat-cepat langsung membantu semampunya(Sutarno, 2019).

Selain berdampak pada kemandirian aspek intelektual, ekonomi, dan sosial, metode yang digunakan guru juga berpengaruh dalam pembentukan karakter kemandirian emosi peserta didik. Kemandirian emosi peserta didik dapat terbentuk ketika guru mengajak peserta didik bermain simulasi dengan mengguakan media arah mata angin, gambar sekolah, uang mainan dan kelereng. Sesuai dengan pernyataan yang dikemukakan oleh Nurla bahwasanya untuk membentuk peserta didik agar tumbuh menjadi sosok berkarakter mandiri, salah satunya dengan memberikan kegiatankegiatan yang merangsang sikap mandiri (Aunillah, 2011).

Peserta didik akan merasakan emosi senang ketika mereka diajak belajar sambil bermain, kemudian peserta didik juga akan belajar bagaimana cara mengelola emosi dengan cara menghargai teman. Meskipun tidak semua peserta didik dapat melakukannya dikarenakan hambatan mereka berbeda-beda. Ada salah satu peserta didik yang emosinya belum terkontrol seperti halnya ketika ia terlalu senang saat bermain kelompok, tanpa ia sadari ia mencubit temannya. Deni Kurniawan mengatakan bahwa pembelajaran tematik sangat mempertimbangkan pembelajaran baik proses maupun isi materi agar memiliki relevansi dengan sifat anak didik. Sehingga pembelajaran bisa lebih dipahami, berguna, dan sesuai dengan kebutuhan didik, terutama dilihat dari segi tugas-tugas perkembangan (Kurniawan, 2014). Hal ini juga sejalan dengan pernyataan Wulandari bahwasanya dalam kaitannya dengan pembelajaran perilaku adaptif anak disabilitas grahita, materi yang dipelajari untuk mengembangkan sosial disajikan dalam bentuk aktivitas peserta didik dalam berinteraksi, bekerjasama dan bermain dengan temannya (Wulandari, 2017).

\section{Faktor Pendukung dan Penghambat yang dialami Guru dalam Pembentukan Karakter Kemandirian Anak Disabilitas Grahita Kelas IV di SDLB Kaliwungu Kudus}

Faktor pendukung pelaksanaan pembelajaran tematik di SDLB Kaliwungu Kudus antara lain: peserta didik memiliki semangat yang tinggi ketika kegiatan pembelajaran berlangsung, peserta didik memiliki percaya diri yang baik, peran guru 
dalam memilih metode, media, dan bahan ajar sesuai tingkat perkembangan anak, lingkungan yang kondusif, tata tertib sekolah dan peran serta orangtua dalam mengembangkan kemandirian anak. Hal ini Sesuai dengan Wuryandani et al., (2016) yang mengatakan bahwa ada beberapa hal yang mendukung berhasilnya pembentukan karakter melalui pembelajaran, diantaranya pertama, iklim sekolah yang kondusif sangat diperlukan dalam pendidikan karakter. Kedua, pemilihan metode pembelajaran sesuai dengan tingkat perkembangan pesera didik. Ketiga, adanya norma/aturan dalam pelaksanan pendidikan karakter kemandirian. Keempat, keterlibatan orangtua dan masyarakat dalam membangun kerjasama yang erat untuk meningkatkan perilaku peserta didik. Hal ini sesuai dengan pernyataan Wahyuningsih (2018, 2019) bahwa orang tua memiliki peran penting dalam membentuk kepribadian dan karakter anak. Faktor penghambat pelaksanaan pembelajaran tematik di SDLB Kaliwungu Kudus antara lain: IQ anak terbatas yang merupakan suatu hal yang mutlak terjadi pada anak disabilitas grahita dan kondisi kelas serta jumlah guru yang tidak ideal.

\section{KESIMPULAN}

Pelaksanaan

pembelajaran tematik kelas IV di SDLB Kaliwungu Kudus berdasarkan hasil penelitian pembelajaran sudah berjalan dengan baik. Hal ini dibuktikan bahwa peserta didik disabilitas grahita sudah mencapai Kompetensi Dasar (KD) dengan hambatan dan kondisi masing-masing peserta didik. Karakter kemandirian anak disabilitas grahita kelas IV di SDLB Kaliwungu Kudus melalui pembelajaran tematik dapat terbentuk karena guru melakukan beberapa upaya pertama, penerapan strategi dan metode yang bervariatif. Guru menerapkan metode ceramah, metode tanya jawab, metode penugasan, metode bermain simulasi. Kedua, menggunakan media yang inovatif. Guru menggunakan media arah mata angin, gambar sekolah, uang logam, uang kertas, kelereng, spidol dan papan tulis. Ketiga, bahan ajar yang sesuai tingkat perkembangan anak. Guru menggunakan buku ajar tematik kelas II tema 3 sub tema "tugasku sehari-hari di sekolah". Dengan beberapa upaya tesebut, empat aspek kemandirian peserta didik di SDLB Kaliwungu Kudus dapat terbentuk.

Adapun faktor pendukung dari segi internal adalah semangat dan percaya diri peserta didik yang tinggi. Kemudian secara eksternal yaitu peran guru dan lingkungan sekitar (sekolah dan orangtua). Faktor penghambatnya dari segi internal yaitu IQ peserta didik disabilitas grahita terbatas. Kemudian secara eksternal yaitu berupa kelas dan jumlah guru yang tidak ideal. Peneliti selanjutnya disarankan untuk meneliti tentang pembentukan karakter kemandirian pada anak disabilitas grahita lebih luas dan mendalam. Selain itu diharapkan dapat menemukan cara lain agar pembentukan karakter kemandirian pada anak disabilitas grahita dapat tercapai dengan baik.

\section{DAFTAR PUSTAKA}

Afandi, M., Wahyuningsih, S., \& Mayasari, L. I. (2021). Does elementary school teacher performance matter? Cakrawala Pendidikan, 40(1), 242-252. https://doi.org/10.21831/cp.v40i1.3 5284.

Ahmadi, L. K., \& Amri, S. (2014). Pengembangan \& Model Pembelajaran Tematik Integratif. Prestasi Pustaka.

Aunillah, N. I. (2011). Panduan Menerapkan Pendidikan Karakter 
di Sekolah. Laksana.

Evitasari, D., Musyadad, F., \& Sholihah, F. (2021). Kesesuaian RPP Tematik Integratif Dengan Surat Edaran Nomor 14 Tahun 2019. Jurnal Ilmiah "Pendidikan Dasar," VIII(14), 18-34.

Farida, I. (2017). Evaluasi Pembelajaran. Remaja RosdaKarya.

Hajar, I. (2013). Panduan Lengkap Kurikulum Tematik. Diva Press.

Khusfiana. (2019). Wawancara.

Kurniawan, D. (2014). Pembelajaran Terpadu Tematik (Teori, Praktik, dan Penilaian). Alfabeta.

Listiady, A. I. (2017). Model Pendidikan Karakter Anak Berkebutuhan Khusus Melalui Program Kesenian Ketoprak. Jurnal Pendidikan Khusus, 12(2), 48.

Malawati, I., \& Kadarwati, A. (2017). Pembelajaran Tematik (Konsep dan Aplikasi). Media Grafika.

Observasi di SDLB Kaliwungu Kudus. (2019).

Permenristek Dikti RI. (2016). Penyandang Disabilitas.

Prastowo, A. (2015). Menyusun Rencana Pelaksanaan Pembelajaran (RPP) Tematik Terpadu. Kencana.

Primasari, Y., Ulia, N., \& Yustiana, S. (2021). Pengambangan Bahan Ajar Berbasis Kearifan Lokal Budaya Samin Guna Menyukseskan Gerakan Literasi. Jurnal Ilmiah "Pendidikan Dasar," VIII(1), 5162.

Putranto, B. (2015). Tips Menangani Siswa yang Membutuhkan Perhatian Khusus. Diva Press.

Rochyadi, E. (2012). Modul Karakteristik dan Pendidikan Anak Tunagrahita. Universitas Pendidikan Indonesia.

Sultan, M. S. (2015). Pengembangan
Bahan Ajar Bahasa Indonesia Berbasis Kurikulum 2013 yang Mengintegrasikan Nilai Karakter Bangsa di SMP. Jurnal Pendidikan dan Pembelajaran, 22(2), 117.

Sulthon. (2016). Pendidikan Anak Berkebutuhan Khusus. STAIN Kudus.

Sutarno. (2019). Wawancara.

Wahyuningsih, S. (2017a). Lagu Anak Sebagai Media Dalam Mendidik Karakter Anak Usia Dini. Thufula, 5(1), 150-180.

Wahyuningsih, S. (2018). Promoting Children' s Spiritual Intelligence and Personality Development. Jurnal Penelitian, 15(2), 189-201.

Wahyuningsih, S. (2019). The Role of Spiritual Approach in Family Parenting: A Study of Lecturers at Institut Agama Islam Negeri Kudus. Jurnal Konseling Religi, 10(1), 42-60.

Wahyuningsih, S. (2017b). Empowering the Character Education for Indonesian People in Facing ASEAN Economic Community (AEC). The Ist Education and Language International Conference Proceedings Center for International Language Development of Unissula, 832841.

Wulandari, D. R. (2017). Strategi Pengembangan Perilaku Adatif Anak Tunagrahita melalui Model Pembelajaran Langsung. Jurnal Pendidikan Khusus, 12(1), 53.

Wuryandani, W., Fathurrohman, F., \& Ambarwati, U. (2016). Implementasi Pendidikan Karakter Kemandirian Di Muhammadiyah Boarding School. Jurnal Cakrawala Pendidikan, 15(2), 208-216.

https://doi.org/10.21831/cp.v15i2.9 882. 